\title{
Appraisal of the Implementation of the National School Health Policy in Secondary Schools in Nigeria
}

\author{
Ogbe O. Joseph \\ Department of Human Kinetics and Health Education, \\ Delta State University, Abraka, Nigeria
}

Doi: 10.36941/ajis-2020-0032

\section{Abstract}

Policies are checks in the execution of programme, hence the National School Health Policy document is meant to guide the promotion of the school Health programme. This study was undertaken to assess the successes and weaknesses of the execution of the National School Health Policy/School Health programme in order to make recommendation in the document. A sample of 184 school principals in Delta state were the respondents. It was an ex post facto, descriptive study. Self design questionnaire was used to solicit information. The questionnaire was derived from the strategies for the implementation of the National School Health Policy. Descriptive statistics of frequency count, percentages and a multiple regression statistics using SPSS 21 was used to analyse the data at 0.05 level of significance. It was found in this study that the National School Health Policy/School Health programme was being significantly executed in Delta state (F-value - 2.935, df $4 / 79$ and alpha, .o22). Among the variables only School Health instruction with $t$ value, -3.034 and alpha at 0.05 was found to be a predictor of comprehensive effective National School Health implementation. Others; principal's awareness, Government monitoring, and School Health - Community relation were not significant as a predictor of the National School Health Policy/School Health Programme. It was recommended among others that the government and other stakeholders in education should improve on the gains so far and set up a power full monitoring term to evaluate the implementation of the National School Health Policy/School Health programme on regular bases in Delta state, Nigeria.

Keywords: National School Health Policy, School Health Programme, Policy and Programme implementation, Delta State, Nigeria

\section{Introduction}

A policy means a course of action or direction to follow/take in order to achieve the goals and objectives of an organsation. According to the Oxford Dictionary of Current English; Policy is a course or action adopted or proposed by an organization or person". Thus, the National School Health policy was put in place in 2006 with the mission of putting in place adequate facilities, resources and programme(s) that will guarantee physical, mental and social wellbeing and the safe and security of the school community that will promote learning outcome of the child (National School Health Policy Implementation Guideline, 2006). By implication carry health information to the family and the larger society. The clue of the goals was to enhance the quality of health in the school community and one of the policy objectives was to put in place a legitimate framework for the mobilization of support for the implementation of the school health policy (National School Health Policy, 2006). 
The implementation was anchored on certain strategies which include; personnel development, infrastructural development, school health services and instructional / skill based instructional development among others.

It has become necessary to evaluate the school health policy implementation for over ten years after the formulation of the policy to ascertain to what extent the policy implementation has been attained. This will provide the background to determine the success or failure of the policy implementation strategies and the goals and objectives of the policy so as to recommend the way forward in Delta State. This appraisal serves as monitoring and evaluation, advocacy, research and knowledge sharing, which this study attempt to attain. At times an independent monitoring and evaluation of programmes such as this research provides a forum for comparison between government sponsored monitoring and evaluation and independent or non-governmental organization monitoring and evaluation.

Ten years ago, the school health policy came into being. Ten years after it is pertinent to assess the success or set-back of the policy as to determine areas of reforms. By so doing, new input can come into the policy and programme as reform. The question could be asked; has the National School health Policy achieved its implementation strategies through monitoring, availability of school health instruction/skill based development, personnel availability and utilization, health service/health appraisal, school health environment/infrastructure and school home/community relationship?

The study was focused on the assessment of personnel, availability and utilization, environment/infrastructure availability, school health services, school health instruction/skill based development and school, home/community relationship.

The National School Health Policy Implementation guidelines have five key heading (1) Healthful school environment, (2) School Feeding Service (3) Skill-based Health education (4) School Health Service and (5) School, Home and Community relationship (implementation guidelines for the National School Health Program, 20o6). This study did appraise the availability and utilization of personnel, environment and infrastructure, health instruction/skill-based development, and school home/community relationship.

The study may be of use to policy formulation and implementation in schools by the Ministry of Education, it will serve as indicators or indexes for policy reforms of the National School Health Policy.

Health educators, school heads/teachers will use it as standard for determining their success or failure in their implementation of the guidelines in their schools. School proprietors will use it as standard for the establishment of new schools and improving on old one. This study is delimited to Delta State, one of the 36 states in Nigeria.

\section{Research Questions}

To address this study, four research questions and one hypothesis were formulated:

1. To what extent are principals/school heads aware of the content of the National School Health Policy implementation guideline document among secondary school principals in Delta state?

2. To what extent does government or their agency monitor and evaluate the implementation of the National School Policy Programme/School Health in Delta State Secondary Schools in delta state

3. To what extent is school skilled based health instruction implemented along the National health policy guideline/school health programme in secondary schools in Delta State?

4. What is the relationship between the school health programme and the host community on the implementation of the National School Health Policy among secondary schools in Delta State, Nigeria? 


\section{Hypothesis}

Principals/Heads of school awareness of the National School Health Policy implementation guidelines, government monitoring of the school health programme, school personnel availability and utility, school health instruction/skill based development, school - community relationship will not significantly predict implementation of the National School Health Policy/School health programme in secondary schools in Delta state.

\section{Theoretical Framework for School Health Programme}

William Kane purposed the wheel of comprehensive Health Education (Andpaugh and Ezell, 2001) cited by Onwuama and Obiaha (2011). According to Onwuma and Obioha (2011) have associated the wheel of comprehensive health education with students as the focus of quality health promotion in the classroom, school, home (family) and community. Spokes of the wheel represent ingredients that enable the students to assimilate healthful behaviour through the support of the school, home and community".

\section{Review of Literature Related to the Implementation of the Guideline on National School Health Policy}

Some studies were reviewed on the implementation of the National School Health Policy.

Onwuama, and Obioha, (2011) reviewed health instruction, food services, healthy school living environment/infrastructure and school health services and found that health instruction exist, in the primary and secondary curriculum in Abuja, Nigeria. About sixty-three percent (63.5\%) agreed that health instruction is always in the curriculum while about sixty-seven percent (67.2\%) said it is taught always. The study revealed that one major balanced diet was served a day in about $46.70 \%$ schools, School health services were provided in schools at more than $43.50 \%$. Obembe, Osungbade and Ademokun (2016) reported in their study that about $2 / 3$ of their participants had never heard of the National School Health Policy document and about $1 / 2$ of the participants were aware of the existence of the school health programme in their schools. That only about 50 years old teachers and post-graduate qualification holders were predictors of significant good knowledge of school health programme.

Ayodeji, Modupe and Onakeko (2016) reporting on school health programme stated that the majority of the teachers who participated in their study had inadequate knowledge of school health programme. Ibhafidon and Moronkola (2008) found in their study that Nomadic primary schools in Southwest Nigeria generally have no healthful living school environment as toilet facilities, potable water, school mark, good school buildings and seating facilities were found to be significantly inadequate.

The implementation guideline for National School Health Programme stated that the monitoring and evaluation committees as constituted at all levels will be responsible for the overall supervision, monitoring and evaluation (implementation guideline, 2006).

In a study, Olatunya, Oseni, Oyalami, Adegbenro, and Akani (2014) reported that $79.4 \%$ of the participants in their study had qualification for teaching in secondary schools, only $3 \%$ of the teachers had in-service training on health in the past five years. About $1.6 \%$ of the participants ever taught emotional health, $4.7 \%$ ever taught communicable diseases and $56.0 \%$ ever taught safety education. Only $4.7 \%$ ever had health instruction taught by a qualified health education staff. According to the report, no school had at least three periods a week as recommended. Compliance with the school health programme was very poor. In another study, Oluwakemi, Kayode, Taiwo and Obembe (2014) reported in their study that $61.9 \%, 52.4 \%$ of the participants report poor implementation of healthful school environment and school health service respectively while skill based health instruction was reported good at $100 \%$. Reporting on problems and challenges of school health nursing in AkwaIbam and Cross - River state, Nigeria, Akpabio (2010) stated the low coverage of school health programme in Cross - River state 3.0\% and Akwa - Ibom 7.2\%. On the scope of school health 
services practice by nurses; treatment of minor illness was $100 \%$, referral services $81.7 \%$, First - Aid $16.7 \%$, Health education $41.7 \%$. Only $18.3 \%$ of the respondents were satisfied with equipment availability for the school health programme.

Azure, Ulasi, Ebenebe, Ekwochi,; Onah, Nduk and Asinobi (2016) stated that $78.6 \%$ had an adequate implementation of school health instruction. According to the study, the proportion of school that met adequate implementation of school instruction was not significant between public and private school in primary schools in a local Government in South - East, Nigeria. Adeniran (2016) reported in a study that only $7.2 \%$ had good knowledge of school health programme while $58.9 \%$ had fair knowledge. Knowledge of school health policy was about $60 \%$. About $94.6 \%$ of the school had functional First Aid Box while $\mathbf{2 8 . 6 \%}$ had a staff in each of their building trained.

\section{Method and Materials}

The descriptive study of the expost-facto design was the design choice for the study. The population was 467 secondary schools in Delta State. The respondents were 184 schools. The respondents sample school size was informed by Researchers claim that 184 minimum is required for a study of less than 10000 population (Ikponowosa, 2006, Areoye, 2004). To obtain the respondents, Delta State secondary schools were clustered on local government bases. The Local Government Areas were 25 . The Local Governments were listed in a sampling frame starting alphabetically. A sampling interval of 2 was adopted. This systematic sampling provides opportunity for proportionate sampling. Thus, 184 schools were sampled across the state. The principal of each sampled school becomes a respondent.

A 30 item questionnaire was developed by the researcher with Section A for bio- data of respondents and Section B for statements soliciting answers to research interest. The respondents were asked to indicate their level of agreement or non-agreement (or acceptance or non acceptance) with Liekert like Scale of 4 points: strongly agreed -4 , agreed -3 , disagree -2 and strongly disagree -1 . The questionnaire was subjected to validity by three experts - two in health education and one in test and measurement. All three saw the questionnaire as ideal and pass it for the study. The statement items were subjected to Cambach alpha, which stood at 82.4, after removal and modification of the items. The questionnaire was administered to school heads during the school hours either directly or through research assistants. Questionnaires were retrieved within 24 hours of administration. Obtained data were analysed using frequency counts, Percentages, benchmark, and multiple regression analysis at 0.05 alpha. SPSS 21 was used to calculate the data. The beach mark was obtained using the mean of the questionnaire scale which stood at 2.5 and above as an agreement or acceptance level. The benchmark will determine the point of acceptance or rejection of the quantitative data.

\section{Findings}

Table 1: Frequency Counts and Percentages of Principals/Head of Schools Awareness of the existence of the National School Health Policy

\begin{tabular}{|c|c|c|c|c|c|c|c|}
\hline S/N Items & & $\begin{array}{l}\text { SA } \\
\%\end{array}$ & $\begin{array}{l}\mathbf{A} \\
\%\end{array}$ & $\begin{array}{l}\mathbf{D} \\
\%\end{array}$ & $\begin{array}{c}\text { SD } \\
\%\end{array}$ & $\begin{array}{l}\text { Mean } \\
\text { Score }\end{array}$ & Decision \\
\hline $\begin{array}{l}\text { As a school head, I am aware of the } \\
\text { school health policy document. }\end{array}$ & $\mathrm{o}^{\mathrm{a}}$ & oo.o & $0^{\mathrm{b}} 98^{\mathrm{a}} 55.55294^{\mathrm{b}} 68^{\mathrm{a}}$ & 37.16 & $136^{b} 17^{a} 9.2917^{b}$ & 2.44 & NA \\
\hline $\begin{array}{l}2 \text { My teachers are aware of the school } \\
\text { health policy document. }\end{array}$ & $\mathrm{o}^{\mathrm{a}}$ & oo.o & $0^{\mathrm{b}} 33^{\mathrm{a}} 18.099^{\mathrm{b}} 117^{\mathrm{a}}$ & 63.93 & $234^{\mathrm{b}} 33^{\mathrm{a}} 18.0733^{\mathrm{b}}$ & 2.00 & NA \\
\hline $\begin{array}{l}3 \text { My teachers and me have seen the } \\
\text { school health policy document. }\end{array}$ & $\mathrm{o}^{\mathrm{a}}$ & oo.o & $o^{\mathrm{b}} 16^{\mathrm{a}} 8.7448^{\mathrm{b}} 66^{\mathrm{a}}$ & 36.06 & $132^{\mathrm{b}} 101^{\mathrm{a}} 55.1910^{\mathrm{b}}$ & 1.50 & NA \\
\hline \multirow[t]{2}{*}{4 A copy of the school health policy } & $\mathrm{o}^{\mathrm{a}}$ & oo.o & $o^{b} 16^{a} 8.7448^{b} 82^{a}$ & 44.80 & $164^{b} 85^{a} 46.4485^{b}$ & 1.62 & NA \\
\hline & & $\begin{array}{l}\text { Agreed } \\
22.75\end{array}$ & & $\begin{array}{c}\text { Disagreed } \\
77.23\end{array}$ & & $\begin{array}{l}\text { Disagreed } \\
1.89\end{array}$ & NA \\
\hline
\end{tabular}


Table 1 revealed that participants principals/school Heads and their Teachers in this study were not aware of the National School Health Programme document in secondary schools in Delta State. Thus, the participants scored an agreement aggregate means of $22.75 \%$ and a disagreement aggregate means of $77.23 \%$. All items on the benchmark were not accepted and overall benchmark of 1.89 .

Table 2: Frequency Counts and Percentages of Government monitoring of the implementation of the National School Health Policy/School Health Programme in Secondary Schools in Delta State

\begin{tabular}{|c|c|c|c|c|c|c|c|}
\hline \multicolumn{2}{|c|}{$\overline{\text { S/N Items }}$} & \multirow{2}{*}{$\begin{array}{l}\text { SA } \\
\%\end{array}$} & $\mathbf{A}$ & D & SD & \multirow{2}{*}{$\begin{array}{l}\text { Mean } \\
\text { Score }\end{array}$} & \multirow[t]{2}{*}{ Decision } \\
\hline & & & $\%$ & $\%$ & $\%$ & & \\
\hline 5 & $\begin{array}{l}\text { Government personnel visit the school } \mathrm{o}^{\mathrm{a}} \\
\text { to assess the availability of personnel } \\
\text { for school health. }\end{array}$ & 00.0 & $0^{b} 34^{a} \quad 18.5102^{b} 82^{a}$ & 44.80 & $136^{b} 67^{\mathrm{a}} 36.6167^{\mathrm{b}}$ & 2.44 & NA \\
\hline 6 & $\begin{array}{l}\text { Government personnel visit the school } 49^{\text {a }} \\
\text { to assess the availability and utility of } \\
\text { school facilities. }\end{array}$ & 26.77 & $196^{\mathrm{b}} 34^{\mathrm{a}} 18.57102^{\mathrm{b}} 51^{\mathrm{a}}$ & 27.86 & $234^{\mathrm{b}} 49^{\mathrm{a}} 26.7749^{\mathrm{b}}$ & 2.00 & NA \\
\hline 7 & $\begin{array}{l}\text { Government personnel visit the school } \mathrm{o}^{\mathrm{a}} \\
\text { to assess the level of implementation } \\
\text { of the school health policy in terms of } \\
\text { instruction and medical care. }\end{array}$ & oo.o & $\mathrm{o}^{\mathrm{b}} 51^{\mathrm{a}} 27.86153^{\mathrm{b}} 66^{\mathrm{a}}$ & 36.06 & $132^{\mathrm{b}} 66^{\mathrm{a}} 36.0666^{\mathrm{b}}$ & 1.50 & NA \\
\hline 8 & $\begin{array}{l}\text { Government personnel give } \\
\text { suggestion on the implementation of } \\
\text { the National school health policy. }\end{array}$ & oo.o & $o^{b} \quad 16^{a} 8.7448^{b} 101^{a}$ & 55.19 & $20.2^{\mathrm{b}} 66^{\mathrm{a}} 36.0666^{\mathrm{b}}$ & 162 & NA \\
\hline & Mean Aggregate \% & $\begin{array}{c}\text { Agreed } \\
25.01\end{array}$ & & $\begin{array}{c}\text { Disagreed } \\
74.09\end{array}$ & & $\begin{array}{c}\text { Disagreed } \\
1.93 \\
\end{array}$ & NA \\
\hline
\end{tabular}

Key: ${ }^{(\mathrm{a})}$ frequency count ${ }^{(\mathrm{b})}$ Liekert like scale, NA; not accepted; A accepted.

It was found in table 2 that $22.75 \%$ of participants in this study agreed that Government is monitoring the implementation of the National School Health Policy / School health programme and 77.23\% of the participants disagreed. The mean aggregate was 1.93, thus, not accepted.

Table 3: Frequency Counts and Percentages of Health Instruction/Skilled base development as in the National School Health Policy/School Health Programme implementation in Delta State.

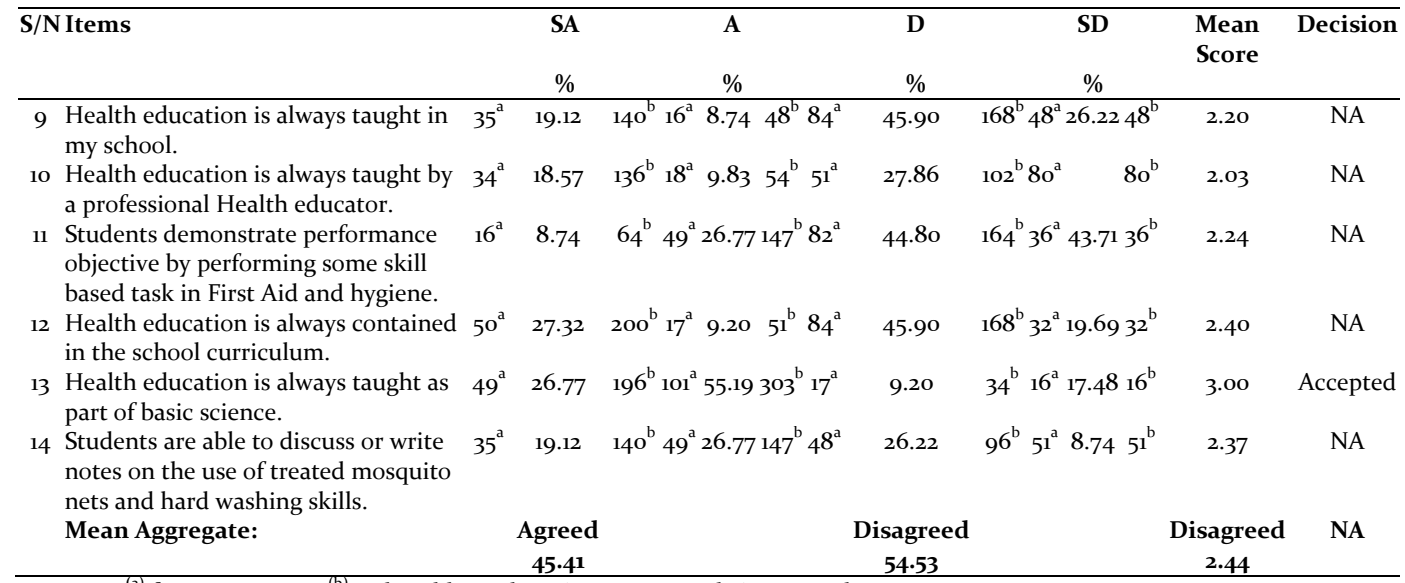

Key: ${ }^{(\mathrm{a})}$ frequency count ${ }^{(\mathrm{b})}$ Liekert like scale, NA; not accepted; A accepted.

Table 3; revealed that the mean aggregate agreement to the effective implementations of the National School health Policy document had $\mathbf{4 5 . 4 1 \%}$ while 54.53 were in disagreement. However, participants agreed at the 3.00 beach mark which was accepted that health education was taught as part of the 
Basic Science Course. Participants also accepted at 2.77 beach mark that students were able to discuss and write notes on the use of related mosquito nets and hand washing $\backslash g$ skill as a means of preventing malaria and other germs causing diseases.

Table 4: Frequency Count and Percentages of School Health - Community Relationship

\begin{tabular}{clcccc}
\hline S/N & Items & Agreed & \% & Disagreed & \% \\
\hline 30 & A Parent/Teacher Association has always existed in my school. & 90 & 48.91 & 94 & 51.08 \\
31 & Teachers visit student's home as follow-up & 64 & 37.78 & 120 & 62.22 \\
32 & Parents visit school to contribute to the teaching - learning & 82 & 44.56 & 102 & 55.43 \\
& process by making suggestion. & & & & \\
33 & Community is always involved in school health programme. & 80 & 43.47 & & 56.52 \\
& & & $\mathbf{4 3 . 6 7}$ & $\mathbf{5 6 . 3 3}$ \\
\hline
\end{tabular}

Table 4 revealed that participants in the study shared the opinion that $56.33 \%$ showed unsatisfactory school health - community relationship.

Table 5: Multple-linear regression statistics of principals' awareness, Government monitoring, school base skill health instructional school health - community relation as predictor of comprehensive National school health policy implementation guidelines/school health programme among secondary schools in Delta state.

\begin{tabular}{|c|c|c|c|c|c|}
\hline & \multicolumn{5}{|c|}{ Coefficient } \\
\hline & \multicolumn{2}{|c|}{$\begin{array}{c}\text { Unstandadized } \\
\text { co-efficient }\end{array}$} & $\begin{array}{l}\text { Standardized } \\
\text { coefficient }\end{array}$ & $\mathbf{t}$ & Sign. \\
\hline & $\mathbf{B}$ & Std error & Beta & & \\
\hline Constant principal & 32.586 & 1.928 & .023 & 16.905 & .000 \\
\hline - Awareness & .011 & .034 & .032 & .313 & .755 \\
\hline - Monitoring & .025 & .058 & -.221 & .435 & .464 \\
\hline -School skill board health instruction & -.284 & .094 & -.084 & -3.034 & .003 \\
\hline \multirow[t]{3}{*}{-School health community relation } & -.127 & .112 & & -1.131 & .260 \\
\hline & \multicolumn{5}{|c|}{$\begin{array}{c}\text { Dependent Variable - Comprehensive National School } \\
\text { Policy/School Health Programme }\end{array}$} \\
\hline & $R, .248$ & $\mathrm{R}^{2}$ R. 0.062 & Adjusted $\mathrm{R}^{2} .041$ & & \\
\hline
\end{tabular}

Table 5 revealed that the $\mathrm{F}$ - value was $.022 \mathrm{df} 4 / 79$ at alpha of .022. Thus rejecting the hypothesis that principal's awareness, Government monitoring, skill based health instruction and school health community relation is a jointly predictor of comprehensive National school policy implementation and school health programme in Delta secondary schools. When the individual variables were subjected to coefficient analysis, it was revealed that only skill based health instruction was a predictor of the National school health policy implementation/school health programme in Delta state. With $\mathrm{R}^{2}$ of.062, it was revealed that all variables in the study contributed $6 \%$ change in the dependent variable.

\section{Discussion}

Health education could be best taught by a Health educator or a Health education teacher. Such a teacher becomes a guide to a principal or school head for the promotion of Health education programmes. The descriptive statistics showed that most principals/school heads were judged to be unaware of the National school health implementation document at an aggregate mean of $77.23 \%$ while $22.75 \%$ claimed to be aware. On Government or her agency monitoring, it was found in this study that $74.09 \%$ of participants claimed that the National school health policy/school health 
programme was not being effectively monitored. While $25.01 \%$ stated that they were satisfied with government monitoring. The study also revealed that skilled based health instruction was also poorly implemented by $53.5 \%$ supporting average or fair implementation while $45.41 \%$ claimed that health instruction was alright. School health - community relation was found to be close to a balance. However, participants assessed $55.14 \%$ not be satisfied while $44.84 \%$ expressed satisfaction.

When the variables were subjected to a multiple regression statistics, it was that all variables combined produced an F-value of 2.935 with a DF of $4 / 97$ and significant at 0.05 level of significant. Thus, the study rejected the hypothesis and stated that the variables when combined can predict effective, comprehensive national school health policy/school health programme. This finding collaborates the findings of Osuorah, Ulasi, Ebenebe, Ekwochi, Onah and Asinobi (2016) and Onwuama and Obioha (2011) who opinioned that the National school health policy/school health programme were being satisfactorily executed in their study areas.

However, when the data were exposed to coefficient analysis, it was found that only school skilled based health education instruction was significant with a negative of -3.034 and significant at.o03 levels of significance. This was similar to the findings of Oluwakemi, Kayode, Taiwo and Obembe (2014) who reported in their study that skilled based health instruction was good in their study at $100 \%$ as assessed by the participants. However, this study was at variance with that of Oseni, Oyalami, Adegbenro and Akani (2014) who stated that only $4.7 \%$ of their participating schools had health instruction taught by a qualified health teacher.

On principals awareness and knowledge of the existence of the National school health Policy implementation document, it was found in this study that principals/school heads were not much aware of the document and it does not exist in their schools. Statistically, $77.23 \%$ were not aware while $22.75 \%$ claimed to be aware. The aggregate mean was 1.89 . This finding failed to meet the means bench mark of satisfaction. It was also not significant when computed at 0.05 levels of signification, recording a t-value of.313 at alpha of.755, thus the hypothesis accepted that principal's/school heads awareness cannot predict effective, comprehensive implementation of the National school health policy/school health programme in Delta state. This finding tally with the finding of Adeniran (2016) and Ayodeji, Modupe and Onadeko (2015) who reported in their study that principals and teachers had inadequate awareness levels and knowledge of the National school health policy/school health programme. This was also the findings of Obembe, Osungbade and Ademokun (2016) who reported that one - third of the participating teachers in their study never ever heard of the National school health policy document. It was also found in this study that Government and stakeholders do not effectively monitor or evaluate the activities and implementation of the National school health policy/school health programme in Delta. The mean aggregate score was $25.01 \%$ reporting satisfactory monitoring while $74.09 \%$ were not satisfied with the level of monitoring. The variable failed to meet the benchmark of satisfactory performance when it scored 1.93. Monitoring had a t-value of.435 at alpha of.664 indicating that monitoring is not a predictor of effective implementation of the National school health policy/school health programme. There was no study on monitoring of the policy in Literature to which to make reference at least to this research. This becomes a prime finding for further reference. It was found in this study that school Health community relationship was not satisfactory with an aggregate mean of 43.67 for and 56.33 against. School Health - community relation was adjusted not to be significant with a t-value of 1.131 in.26o alphas. Reference literature on school Health - community relation has not be given much prominence in literature, hence, previous study were not available as reference point.

\section{Conclusion}

In this study, it was focused on the National School Health Policy/School Health Programme satisfactorily executed in Delta State. School skill based health instruction was found to be satisfactorily executed and found to be a predictor of an effective National School Health Policy 
programme in Delta state. However, the variable of Principals/Head of school awareness level, monitoring of the policy/programme and school health - community relation were unsatisfactory, being implemented as they were unsatisfactory at the descriptive statistics level and were found not to be significant predictors of effective comprehensive school Health Policy / School Health Program.

\section{Recommendations}

Arising from the findings, the following recommendations were made:-

1. Government and other stakeholders in the education sector should improve on the gain already made.

2. The government should make better provision for the monitoring and evaluation of the National School Health Policy/School Health Programme.

3. School skill base Health instruction should be given better attention, especially now that Health education is now a West African Examination Council examination subject. This calls for the employment and training of Health education Teachers to improve on the gain so far.

4. Governments, teachers and parents should promote better school health - community relationship as improving the health of the child in the school is improving the community health.

\section{References}

Adeniran, A. (2016). School health programme a practice among private secondary school administrators in Urban Local Government Area in Lagos Nigeria. International Journal of Community Medicine and Public Health 3 (1) $240-245$.

Akpobio, I. I. (2010). Problems and Challenges of School Health Nursing in Akwa - Ibom and Cross River state. Continental J. Nursing 2, $17-28$.

Araoye, M. O. (2004). Research Methodology for Health and Social Services, Ilorin: Nathadex Publishers.

Ibhafidon, A. \& Moronkola, O.A. (2008). Evaluation of Healthful School Environment in Nomadic Primary Schools in South Western Nigeria, West African Journal of Physical and Health Education. 12, 251-261.

Ikponowosa, O. (2013). Fundamentals of Statistics in Education and the Social Sciences;. National Books Publisher.

National School Health Policy, (2006), Federal Ministry of Education, Nigeria.

National School Policy Implementation guidelines (2006). Federal Ministry of Education, Nigeria

Obembe, Osungbade \& Ademokun (2016). Awareness and knowledge of National School Health Policy Programme among Public and Private secondary school teachers in Ibadan metropolis. Niger Medical journal, 57 (4), $217-225$.

Olatunya, O. S., Oseni, S. B., Oyalami, O. A, Adegbenro, C. \& Akani, N. (2014). Health Instruction in Nigeria school; the missing links. Pan - Africa MED. Journal 19 360. 10.11604/Pami 2014 19.360.4587.

Oluwakemi, M; Kayode, O. Taiwo A; \& Obembe (2014). A qualitative study on status implementation of school health policy in South-Western Nigeria. American Journal of Educational Research 2 (11)

Onwuma, M. \& Obioha, C. (2011). Assessing strategies of school health programme as a tool for quality primary Health care goals in secondary schools in Federal Capital Tertiary, Abuja. Nigerian School Health Journal, 23 (1) in $54-65$.

Osuorah, D. I. C., Ulasi, O. T., Ebenebe, J., Ekwoch, U., Onah, K. S., Nduk, I. \& Asinobi (2016). Assessment of School Health Instruction Implementation in Primary schools in Local Community in South - East Nigeria: A comparative study between private and public schools. British Journal of Medicine and Medical Research $2016(7) ; 1-6$.

Oxford Dictionary of Current English $-9^{\text {th }}$ edition, 2001. United State, Oxford University Press. 